UDC 35.085

DOI: https://doi.org/10.32782/2224-6282/164-21

Tsviliy Sergiy, Vasylichev Denys, Gurova Darya National University «Zaporizhzhia Polytechnic»

Цвілий С. М.

кандидат економічних наук, доцент, Національний університет «Запорізька політехніка» ORCID: https://orcid.org/0000-0002-1720-6238

Василичев Д. В.

кандидат економічних наук, доцент, Національний університет «Запорізька політехніка» ORCID: https://orcid.org/0000-0002-5057-7575

Гурова Д. Д. кандидат економічних наук, доцент, Національний університет «Запорізька політехніка» ORCID: https://orcid.org/0000-0002-3180-0348

\title{
TRANSFORMATION OF THE PERSONNEL MANAGEMENT SYSTEM OF A TYPICAL HOSPITALITY ENTERPRISE INTO AN INNOVATIVE STRUCTURE
}

The article analyzes the social and labor processes occurring in the hospitality industry. The general algorithm of transition to the new personnel management system of innovative type for the company in the field of hospitality is investigated. Regularities of innovative development of personnel management systems at a typical enterprise in the field of hospitality and their characteristics are revealed. The following steps for the transition to a system of "human resource management" are proposed: the formation of the principles of social partnership; creation of differentiated subsystems that are focused on individual social groups; decentralization of personnel management and transformation of the relevant specialized service into a consulting and methodological one with some integration into other enterprise management systems; development of forms of relations that allow investing in staff development; development of motivational bases of management, formation of collectives focused on creativity and self-organization.

Keywords: personnel, hospitality enterprise, structure, management, system.

JEL classification: M12

\section{ТРАНСФОРМАЦІЯ СИСТЕМИ УПРАВЛІННЯ ПЕРСОНАЛОМ ТИПОВОГО ПІДПРИЕМСТВА СФЕРИ ГОСТИННОСТІ В ІННОВАЦІЙНУ СТРУКТУРУ}

\begin{abstract}
Проведено аналіз сочіально-трудових прочесів на підпиємствах сфери гостинності, який довів, що найбільщу питому вагу має тип системи «відділ кадрів», який характерний для початкової стадії індустріального періоду. Встановлено, щзо інтенсивні чинники ефективного зростання і розвитку персоналу не залучаються до процесів перетворень та коронавірусних трансформацій. Зазначено, щзо загальний алгоритм переходу до нової системи управління персоналом інноваційного типу для компанії сфери гостинності складається з побудови дієвого фундаменту, включаючи розвиток об'єкта та суб'єкта управління; впровадження системи управління; дії механізмів функиіонування системи управління; підготовки основ для переходу до системи наступного типу у режимі вдосконалення, формуванні системоутворюючих елементів; реорганізації. Виявлено закономірності інноваційного розвитку систем управління персоналом на типовому підприємстві сфери гостинності та їх характеристику. Доведено, щчо для переходу до системи «управління персоналом» повинні бути такі передумови трансформащії, а саме: розвиток компетентностей суб'єктів у питаннях управління персоналом; застосування контрактних форм відносин між роботодавием та найманим праиівником; перебудова архітектури системи з виробничо-функціональної на проектноспрямовану; створення мотивації прачівників, яке спрямовано на розвиток, ініиіативність й творчість. Встановлено, щио перехід до системи «управління персоналом» може бути більш швидким. Запропоновано кроки для переходу до системи «управління людськими ресурсами»: формування принципів соиіального партнерства; створення диференційованих підсистем, які орієнтовані на окремі сочіальні групи; дещентралізація управління персоналом і перетворення відповідної спеціалізованої служби у консультаційно-методичну з інтеграцією в інші системи управління підприємством; розробка форм відносин, які дозволяють інвестувати у розвиток персоналу; розвиток мотиваційних основ управління, формування колективів, щьо оріснтовано на креативність та самоорганізацію.
\end{abstract}

Ключові слова: персонал, сфера гостинності, структура, управління, система.

Formulation of the problem. Recent research has found that staff is a key resource for managing organizational change in hospitality companies. From the standpoint of a systems approach, the innovative development of the

(C) Tsviliy Sergiy, Vasylichev Denys, Gurova Darya, 2020 personnel management system of enterprises is an urgent scientific task. The substantiation of compliance with the principles of the theory of organizational change of the personnel management system of a typical hospitality 
company is the statement of scientists about the changes of abrupt format, where at each previous stage the preconditions for reorganization are created. As a result, objectively the question arises about the pace of change in the types of personnel management systems. In other words, how long can and should the system work within the old paradigms of personnel management, and what should be the way to "jump" to the new system.

Analysis of recent research and publications. At first glance, the theoretically correct position is that the faster the change of types, the faster the system will acquire the characteristics of a more perfect, which corresponds to modern ideas of science (I. Ansoff, K. Bahrinovsky, M. Bendikov) [1]. According to B. Karloff and S. Söderberg, we should not forget about the factors influencing the formation of this system [2]. As proved by A. Karpenko, L. Bukharina, O. Onyshchenko, in each of the periods of development of economic entities, the strength and nature of the influence of various factors differs significantly and depends on the overall level of economic development [3]. Confirmation is the fact (S. Tsviliy, D. Vasylychev, D. Gurova) that the personnel management system is a part or subsystem of more general systems (enterprise management, regional management, management of social and labor processes of society) [4].

The purpose of the article is improving the personnel management system, which is essentially part or subsystem of more general management systems of hospitality enterprises, by optimizing the impact of various factors that differ significantly and depend on the overall level of economic development of economic entities.

Presenting main material. Most scientists recognize that the current stage of development of Ukraine's economy is characterized by signs of the industrial period with the properties of the advantages of personnel management system over other types. However, the analysis of social and labor processes occurring in the hospitality industry, showed that the type of system "personnel department", characteristic of the initial stage of the industrial period [5]. This situation indicates the underdevelopment of the personnel management system at a typical hospitality enterprise (THE) and becomes one of the main obstacles to the development of services and the country's economy, as intensive growth factors in the effective use and development of its labor potential are not involved in the process of market transformations and coronavirus transformations [6].

The reason for this situation is that in the early stages of the radical transformation of the economy the issue of social and labor relations was not given due attention, the lack of prerequisites for the transition from a system of "personnel department" to "personnel management". In turn, attempts to quickly overcome problems and transition to systems such as "personnel management" face resistance of personnel to innovative changes, due to distortions in the motivational structure of the management object, underdevelopment of management entities, inconsistency of technologies in the content structure of management system THE staff. Most scholars acknowledge that the current stage of development of Ukraine's economy is characterized by signs of the industrial period. It has the advantage of a personnel management system over other types. At the same time, the analysis of social and labor processes taking place at the enterprises has shown that the type of system "personnel department" characteristic of the initial stage of the industrial period remains important. This allows us to conclude that the underdevelopment of personnel management in enterprises is one of the main obstacles to economic development, as intensive growth factors in the effective use and development of its labor potential are not involved in market transformation processes. The reason for this situation is that in advance, at the beginning of the radical transformation of the economy, issues of social and labor relations were not given due attention, no preconditions were created for the transition from a system of "personnel department" to "personnel management". Attempts to quickly overcome the accumulated problems and rapid transition to systems such as "personnel management" face resistance of personnel to innovative changes due to distortions in the motivational structure of the management object, underdevelopment of management entities, and inconsistency of technologies in the content structure of personnel management system [2].

The general algorithm of transition to the new personnel management system of innovative type for the company of hospitality sphere looks as follows: construction of the base, bases of system, including development of object and subject of management (1); implementation of a management system (2); adjustment of the mechanisms of functioning of the control system, as a result of which it should give its maximum possible effect at this point in time (3); preparation of bases for transition to the system of the next type in the mode of improvement, including formation of system-forming elements (4); reorganization (5). Figure 1 illustrates the general cycle in compliance with the principles of cyclicity, evolution, abrupt development, continuity and sequence [7].

The following regularities of innovative development of THE personnel management systems and their characteristics are revealed.

First, changes in the system-forming principles of the personnel management system, the main processes of which were the organization of labor (rationing and regulation of labor, organization of jobs as an organizational and technical factor of the labor process), labor incentives (efficiency and remuneration) and personnel evaluation (certification and compliance of the employee with the requirements of the workplace). In a system such as "personnel management" labor incentives give way to work motivation due to the conditionality of labor efficiency performance indicators, characteristics of labor behavior, expanding the range of incentives for staff to work. The qualitative content of personnel evaluation is changing, which is based on the evaluation of professionally important qualities, which, in turn, are a reflection of the requirements of the workplace and social environment of THE, corporate interactions (loyalty, devotion, ability to develop). The organization of labor is more seen as a socio-economic subsystem and shows the need for fuller inclusion of the individual in the labor process [7].

In systems such as "human resource management", which are identified with the post-industrial period of economic development, the element of "personnel development" is among the system-forming instead of the element of "division of labor". This is due to the influence of the theory of strategically oriented management concept and the theory of human capital and is reflected in the greater integration of staff into the number of elements and conditions of strategic development of the enterprise. As a basic, among 


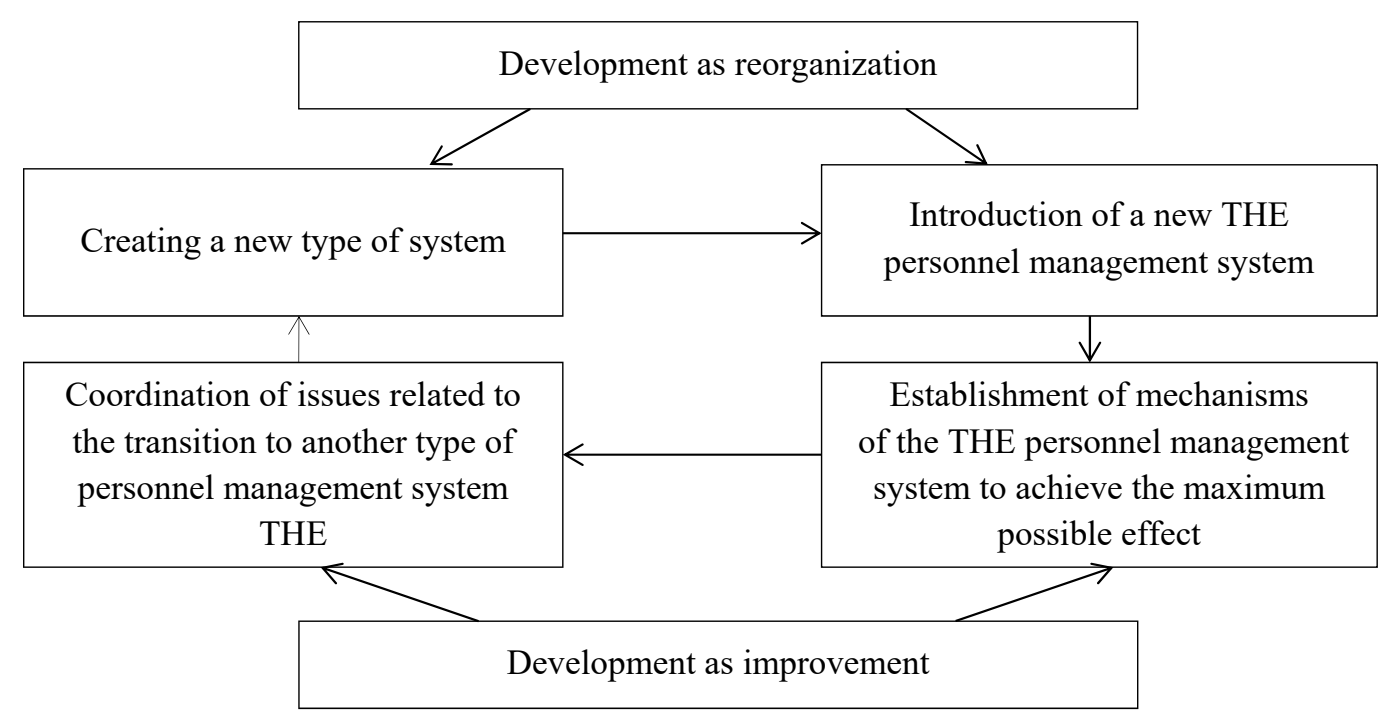

Figure 1. The general cycle of innovative development of the THE personnel management system

the system-forming, in this type of system is the motivation of labor activity, which is aimed at giving a subjective personal meaning to its employees, to activate the internal determinants of labor behavior. Personnel evaluation is becoming more comprehensive and systematic, and is seen as a prerequisite for management decisions on the whole range of personnel management issues.

Personnel management systems such as "social management", according to many scientists, are characteristic of the information, globalized society and are determined by the theories of intellectual capital and "pulsating" management, based on the principles of self-organization, diversity of their structure, predominance of creativity and knowledge. Therefore, the number of system-forming elements should include such as staff development, evaluation, team building [8].

Staff development in accordance with these theories, determines the development of THE in an unpredictable, dynamic market environment. It should take place according to the schemes of advanced development. In this case, the main qualities of staff should be: the complexity of knowledge (finding solutions at the border of science and activity), the ability to implement the idea, the ability to work in a team, informal leadership. Since in the conditions of social management the predominance of contractual forms of relations, project-oriented temporary social groups for realization of set of business processes is forecasted, such new element as "formation team" should enter into number of system-forming ones. This involves special specific forms of organization of selforganized teams and can be considered as a modified process taking into account the development of the element "labor organization", which, unlike other stages, aims to use a set of conditions for the creation, operation and development of teams. "Personnel assessment" as a system-forming element is transformed into the creation of an information database for the formation of mobile teams for individual business processes, assessment of the degree of development of qualities and others.

Secondly, changes in the content of social and labor relations. In systems such as "personnel department" is dominated by the principle of paternalism, which is impersonal in nature and subordination to the production process. In the systems of "personnel management", which are based on the principles of social partnership, intersubjective relations begin to emerge and develop, the role of personnel as a subject increases, the sphere of relations includes issues of meeting the social needs of the employee, protection of his rights and freedoms. In a system such as "human resource management" come to the fore relations that are associated with the development of THE, and therefore, the relationship is based on the contradictions between the qualities of the employee and their compliance with the strategy of the hospitality enterprise. Thus, remaining the owner of "human capital", which determines the pace and nature of THE development, the employee acquires a high degree of independence in making decisions about the scope of their work, which is the basis for the formation of corporate culture.

Within the system of the type "social management" the basic relations arise concerning realization of the principle of cooperation which has changed the principle of social partnership. On the one hand, the enterprise, as a form of economic structure, has a purpose, objectives and limits of activity and it needs some organization, which is expressed not in the desire of the subject of management to "order" as opposed to "chaos", but to the intermediate order "constructive chaos". On the other hand, personnel in the conditions of self-determination and self-organization become mobile and independently distribute efforts between spheres of life (work, rest, family, entertainment, etc.). Requirements of intensification of development of knowledge and creativity of thinking dictate expediency of almost full inclusion of the person in structure of the enterprise. Work in such conditions should be a condition of self-development and create preconditions for harmonization of all spheres of its vital activity. As a result, new forms of motivational crisis may emerge, manifested in the fact that work is increasingly becoming an instrumental value (working well, but not for development, as required by social management, but to have more free time).

Third, changes in the organization of personnel management. In this system there is a transition from "structural decisions" to "personal decisions" on the follo- 
wing characteristics: from organizational reorganizations to "readiness for change" (1); from the desire to increase efficiency only through structural optimization to selfdevelopment of staff and the labor market (2); from continuous structural innovations to taking into account self-organization and initiative of individual employees (3); from instructions, reports, bureaucratic combinations to forecasts (4); from vertical management to horizontal management and to "management-coordination", "management-consulting" (5).

Fourth, the development of contradictions and the creation of conditions for the transition to a new type of management system of a typical enterprise in the hospitality industry.

It should be noted that in systems such as "personnel department" the problem is the contradiction between the administrative and technocratic management and the social structure of the enterprise, which is most pronounced in the inadequate assessment of the role and importance of staff as a condition for THE [9]. Overcoming this contradiction is possible through such methods as: centralization of personnel management functions [10]. Despite the discrepancy between the principles of centralization and trends in organizational development, it can be considered appropriate to this stage of development of the system (1); expansion of its functions, which contributes to the inclusion in the scope of purposeful management of a significant number of labor and social processes and relations and indicates the diversity of forms of staff behavior and their impact on the performance of THE (2); expansion of the composition of the subjects, which corresponds to the structure and complexity of social and labor relations, encourages to develop and further optimize the schemes of their interactions and relations (3); formation of a motivational structure of staff that is adequate to market relations. This allows you to develop staff qualities that reflect not only the requirements of the present time, but also are the foundation for the dynamics of the system in the future, because it is the subsystem of personality orientation is the basis for creating processes of self-organization and self-development (4)

For the transition to the system of "personnel management" should be the following prerequisites for transformation: the development of competencies of entities in matters of personnel management (1); application of contractual forms of relations between the employer and the employee (2); restructuring of the system architecture from production-functional to design-oriented (3); creating employee motivation, which is aimed at development, initiative and creativity, which will be the basis in the future for the transition to better systems. In the system of "personnel management" identified a priority problem, which is the contradiction between the subjects of personnel management about their place in the system of social and labor relations, which is manifested in changing the institutional framework of personnel management THE, and its solution will decentralize the system; introduction of the scheme of complex and advanced development of personnel; democratization of personnel management and various systems of personnel participation in enterprise management.
It has been found that the transition to human resource management can be faster. This is evidenced by both the results of empirical research and the experience of modern THE, and the reason is the awareness of the decisive role of staff in the enterprise. That is, in the system of the "personnel department" begins to develop an idea of the importance of the social subsystem not on the principles of past experience (paternalism, limited motivation, impersonal work), but on the principles and in the form of corporate culture.

When creating the preconditions for the transition to the system of "human resource management" it is recommended: the formation of the principles of social partnership (1); creation of differentiated subsystems, which are focused not on personnel management, but on separate social groups (2); decentralization of personnel management and transformation of the relevant specialized service into a consulting and methodological one with some integration into other THE management systems (3); development of forms of relations that allow investing in staff development (4); development of motivational bases of management, formation of collectives focused on creativity and self-organization.

The main problem in the development of a system such as "human resource management" is the contradiction between the need for targeted organizational management, on the one hand, and increasing independence of individual employees, social groups and staff, mobility (development) of staff, on the other. This contradiction is most acute in the relations and processes for the growth of self-organization in personnel management, and its overcoming will contribute to: the development of intellectual capital of the enterprise (1); organization of "business incubators" as a managed process of staff development, which, under certain conditions, become a source of development of subsystems with a focus on social groups (2); creating conditions for selfdetermination of leaders and their economic, social and psychological regulation in the business process (3); development of motivation on the basis of inclusion in subjects, reference social groups (THE collectives on the basis of system of lifelong employment) (4); development of participation systems in the coordination of activities (for profit and for the formation of cooperative relations instead of partnership) (5).

Conclusions. Thus, the presented patterns show the possibilities of innovative development of personnel management systems. The preconditions and conditions of transition from one type of system to another are also defined. Construction of the system taking into account the laws will allow the enterprise in the field of hospitality to quickly achieve the optimal (currently the level of development of theory and science) type of management system. This will lead to the emergence of completely new complex tasks for the subjects of the labor process, and clearly demonstrates the continuity of changes in social and labor relations, which is intrinsic to the development of the system as a constant managerial innovation. The vector of further research in this direction is the study of the transformation of factors influencing the system in the conditions of COVID-19. 


\section{References:}

1. Bagrinovskiy K.A., Bendikov M.A. (2002) Nekotoryye podkhody k sovershenstvovaniyu mekhanizma upravleniya tekhnologicheskim razvitiyem [Some approaches to improving the mechanism for managing technological development]. Menedzhment $v$ Rossii i za rubezhom [Management in Russia and abroad], no.1, pp. 3-19. (in Russian)

2. Bengt, Karlof, Sven, Sederberg (1996). Vyzov liderov: o probleme liderstva v oblasti upravleniya [Leaders' Challenge: On the Problem of Leadership in Management]. (Trans. from Swedish). Moskva: Delo. (in Russian)

3. Karpenko A.V., Bukharina L.M., Onyshchenko O.A. (2019) Innovatsiyne pidpryyemnytstvo yak osnova sotsial'noekonomichnoho rozvytku [Innovative entrepreneurship as the basis of socio-economic development]. Information and Innovation Technologies in Economics and Administration, pp. 122-131. Katowice, Poland. (in Ukrainian)

4. Vasylychev D., Tsviliy S., Gurova D. (2020) Organizational and innovative approaches to the development of labor resources in the service industries in the regional market of educational services. Contemporary technologies in the educational process, pp. 141-148. Katowice, Poland.

5. Karpenko A.V. (2018) Rozvytok intelektual'nykh aktyviv lyuds'koho potentsialu: teoriya ta praktyka [Development of intellectual assets of human potential: theory and practice]. Zaporizhzhia: FOP V.V. Mokshanov. (in Ukrainian)

6. Tsviliy S., Vasylychev D., Gurova D. (2020) Itroduction of process management into the management system of the tourist company on the basis of informatization of business processes. The role of technology in the socio-economic development of the postquarantine world, pp. 37-46. Katowice, Poland.

7. Sokolov A.V., Karpenko A.V., Vasylychev D.V., Vasyl'yeva O.O. (2016) HR-menedzhment na innovatsiynykh pidpryyemstvakh [HR-management at innovative enterprises]. Zaporizhzhia: Dyke pole. (in Ukrainian)

8. Tsviliy S., Gurova D., Korniienko O. (2020) Postcoronavirus development of the regional tourist destination on the principle of public-private partnership. Biznes-navihator [Business-navagator], no. 4 (60), pp. 134-138.

9. Zaitseva V., Tsviliy S., Bublei G. (2019) Innovation facilities of the tourist business of small and medium enterprises of the region [Innovatsiyni mozhlyvosti turystychnoho biznesu malykh ta serednikh pidpryyemstv rehionu]. Roczniki Ekonomiczne KPSW w Bydgoszczy [Economic Yearbooks of the KPSW in Bydgoszcz], no. 12, pp. 201-212.

10. Tsviliy S.M., Vasylychev D.V., Gurova D.D. (2020) Improvement of the qualification of small and micro-enterprise staff in the crisis conditions of business transformation. Ekonomichnyy visnyk DVNZ «UDKHTU» [Economic Bulletin of UDKHTU], no. $1(11) / 20$, pp. 50-60. 